UDC 542.943, 547.313.3, 547.211

\title{
OXIDATIVE CONVERSION OF LOWER OLEFINS AND PARAFFINS OVER THE MODIFIED ZEOLITE CATALYSTS
}

\author{
A.M.Aliyev, F.V.Aliyev, U.M.Najaf-Guliyev, R.I. Akhmadov, T.I.Huseynova, R.Y.Agayeva \\ M.Nagiyev Institute of Catalysis and Inorganic Chemistry, NAS of Azerbaijan
}

\begin{abstract}
With the purpose of development of high efficiency catalysts for reactions of the oxidative conversion of lower olefins and paraffins into the desired products of petrochemical industry it has been synthesized by ion exchange method a range of the metalzeolite catalysts on the basis of synthetic ( $\mathrm{NaY}$ ) and natural (pure and dealuminated clinoptilolite and mordenite) zeolites and the cations of different metals. It has been established that the metalzeolite catalysts prepared on the basis of synthetic zeolite NaY shows relatively high activity in the oxidative conversion of ethylene and propylene into acetaldehyde and acetone accordingly. It has been also synthesized a highly effective metalzeolite catalysts for the processes: oxidative conversion of methane into ethylene; oxidative conversion of propane into acetaldehyde and formaldehyde; oxidative conversion of methane to ethylene and acetylene; oxidative conversion of methane to 1,4-butanediol.
\end{abstract}

Keywords: zeolites, activity, lower olefins, paraffins, oxidative conversion.

doi

\section{Introduction}

The development of high efficiency metalzeolite catalysts for the gas phase reactions of oxidation of ethylene and propylene into acetaldehyde and acetone accordingly as well as for oxidative conversion of methane into ethylene and partial oxidation of propane into acetaldehyde and formaldehyde is of great significance with point of view of industrial realization.

In the literature, by way of the catalysts for oxidation of ethylene and propylene into acetaldehyde and acetone accordingly have been suggested the different salts of palladium on the surface of the different carriers, palladium with additions deposited on surface of aluminum oxide and palladium and copper containing zeolites. From these catalysts, palladium and copper containing zeolites are more perspective which have the relatively high activity [1-4]. Industrial realization of the gas phase oxidation of ethylene and propylene over zeolite catalysts into acetaldehyde and acetone accordingly are required their further improvement by means of selection more efficiency metalzeolites.

Numerous of the literatures data testify that the different mixed oxides of metals show relatively high catalytic activity in the reactions of oxidation of the lower paraffin hydrocarbons [5-7]. Until recently, however little attention had been given to the possibility of employing of the modified zeolites for promoting these reactions. The use of the modified zeolites with different cations for catalyzing the reactions of oxidative conversion of methane into ethylene, acetylene and partial oxidation of propane into lower carbonyl compounds are not described in the literature.

In the present paper has been given the results of the investigation on selection of high efficiency metalzeolite catalysts of oxidation ethylene and propylene into acetaldehyde and acetone accordingly; oxidative conversion of methane into ethylene; partial oxidation of propane into acetaldehyde and formaldehyde; oxidation of propylene to acrolein; oxidative conversion of methane into ethylene and acetylene and oxidative conversion of methane into 1,4-butanediol.

\section{Experimental part}

It has been prepared series of the specimens of metalzeolites modified with cations of the different metals $\left(\mathrm{Pd}^{2+}, \mathrm{Cu}^{2+}\right.$, $\left.\mathrm{Mg}^{2+}, \mathrm{Ca}^{2+}, \mathrm{Sr}^{2+}, \mathrm{Ba}^{2+}, \mathrm{Sn}^{2+}, \mathrm{Li}^{+}\right)$on the basis of synthetic zeolite $(\mathrm{NaY})$ and Azerbaijan natural zeolites (pure and dealuminated clinoptilolite and mordenite). Zeolites modified with the cations of the different metals have been synthesized by ion exchange method [8]. The 
dealuminated forms of zeolites were obtained by processing of clinoptilolite and mordenite with $0.5 \mathrm{~N}$ solution of $\mathrm{HCl} 1-3$ times at $98^{0} \mathrm{C}$ for $2 \mathrm{~h}$. After incorporating of ions all of the specimens of the metalzeolite catalysts were activated with air at temperature $350^{\circ} \mathrm{C}$ and space velocity $2400 \mathrm{~h}^{-1}$ during $30 \mathrm{~min}$.

The test of the activity of the prepared metalzeolite catalysts were carried out for the reaction of oxidation of lower olefins in a flowcirculation apparatus and for the reactions of oxidation of lower paraffins in a flow apparatus with the quarts tube reactors connected directly to the gas chromatographs. The reactor was placed inside the thermostated chamber. Small stainless-steel balls with a $0.2 \mathrm{~cm}$ diameter were placed before the catalytic bed in order to obtain plug flow conditions. No catalytic activity was shown by these nonporous balls. A fraction of granulated metalzeolites of about $0.4 \div 0.8 \mathrm{~mm}$ of equivalent diameters was used as the catalyst. The analyses of the products of the reactions of oxidation of ethylene, propylene and propane were performed by gas chromatograph using a column filled with polusorb-1 (length, $3 \mathrm{~m}$ ). The analyses of the products of reaction of oxidative conversion of methane together with the unreacted reagents were performed by two gas chromatographs LXM-8MD using a hot-wire detector and the columns filled with $\mathrm{Na} 13 \mathrm{X}$ (length, $3 \mathrm{~m}$ ) and polysorb-1 (length, $5 \mathrm{~m}$ ). Argon was employed as the carrier gas in the first chromatograph. This chromatograph was employed for separating $\mathrm{H}_{2}, \mathrm{O}_{2}, \mathrm{CH}_{4}$ and $\mathrm{CO}_{2}$. The second chromatograph helium was employed as the carrier gas and to be analyzed the other products of the reaction with using the program control of the temperature.

The test of the activity of the prepared metalzeolite catalysts for the reactions of oxidative conversion of methane to ethylene and acetylene is carried out in a two-stage reactor with a stepped feed of oxygen. The same experimental method was employed for the reaction of oxidative conversion of methane into 1,4-butanediol.
Type, crystallinity of natural clinoptilolite and mordenite, composition of the zeolite and the metallzeolites have been determined with using of the instruments: BRUKER D2 PHASER and JCP-MS Agilent 7700.

\section{Results and discussion}

The experimental data indicated that metalzeolite catalyst $\mathrm{PdCuNaY}$ containing $1.5 \%$ (wt.) of ions of palladium and 6.0\% (wt.) of ions of copper shows relatively high activity in the reaction of oxidation of ethylene and propylene into acetaldehyde and acetone accordingly. Therefore a selection of active catalyst for these reactions was carried out by means modification of this catalyst with ions $\mathrm{Ba}^{2+} \mathrm{Ca}^{2+}$ and $\mathrm{Sr}^{2+}$ by ion exchange method. Some of the results of this investigation are presented in Table 1.

It can be seen from data of Table 1, the best results are obtained at proceeding the reactions over metalzeolite catalyst $\mathrm{PdCuCaNaY}$. Although it has been known from literature that these reactions carry out with formation of intermediate $\pi$-complexes but apparently these has been phenomenons which are observed in the reactions proceeding on the carbonium-ion mechanism. Influence of degree of exchange ions of $\mathrm{Na}$ with cations of calcium on the catalytic activity is explained by hypothesis according which the activity of the catalyst is determined by existing of the noncompensated electric charge arised because of that one bicharged cation cannot form equivalent bonds with two charged tetrahedron of $\mathrm{AlO}_{4}$. The observed series of activity $\mathrm{Ca}^{2+}>\mathrm{Sr}^{2+}>\mathrm{Ba}^{2+}$ on this hypothesis can be explained by change of intensity of fields with increasing of ion radius of cation. Thus the metalzeolite catalyst $\mathrm{PdCuCaNaY}$ with degree of exchange ions $\mathrm{Na}$ with ions $\mathrm{Ca}^{2+}, 45 \%$ containing of ions of $\mathrm{Pd}^{2+}-1.5 \%$ (wt.) and $\mathrm{Cu}^{2+}-6.0 \%$ (wt.) shows the highest activity in reactions of oxidation of ethylene and propylene into acetaldehyde and acetone accordingly. 
Table 1. The results on the selection of active catalyst for the reaction oxidative conversion of lower olefins

\begin{tabular}{|c|c|c|c|c|c|c|c|c|c|c|c|}
\hline \multirow[b]{2}{*}{ № } & \multirow[b]{2}{*}{ 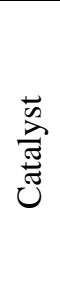 } & \multirow[b]{2}{*}{ 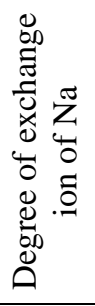 } & \multirow[b]{2}{*}{ 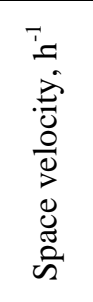 } & \multirow[b]{2}{*}{ 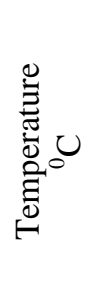 } & \multirow[b]{2}{*}{ 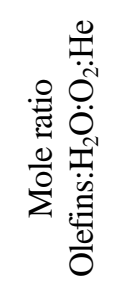 } & \multicolumn{3}{|c|}{ Oxidation of $\mathrm{C}_{2} \mathrm{H}_{4}$} & \multicolumn{3}{|c|}{ Oxidation of $\mathrm{C}_{3} \mathrm{H}_{6}$} \\
\hline & & & & & & 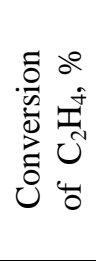 & 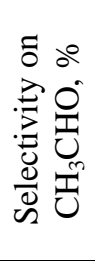 & 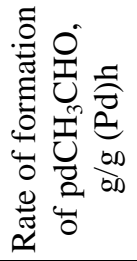 & 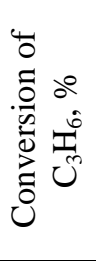 & 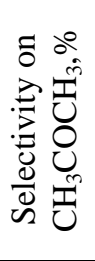 & 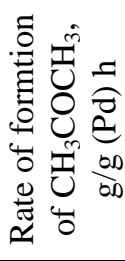 \\
\hline 1 & \multirow{9}{*}{ 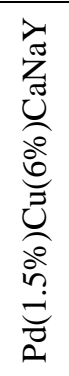 } & 37 & 1200 & 105 & $1: 2: 2: 3$ & 58.3 & 96.7 & 31.8 & 58.1 & 98.8 & 42.7 \\
\hline 2 & & 37 & 1200 & 115 & $1: 2: 2: 3$ & 63.3 & 94.4 & 33.6 & 60.6 & 97.4 & 43.9 \\
\hline 3 & & 37 & 1200 & 125 & $1: 2: 2: 3$ & 64.2 & 90.0 & 32.6 & 63.0 & 92.1 & 43.2 \\
\hline 4 & & 45 & 1200 & 105 & $1: 2: 2: 3$ & 65.7 & 96.5 & 35.8 & 62.1 & 98.3 & 45.5 \\
\hline 5 & & 45 & 1200 & 115 & $1: 2: 2: 3$ & 72.8 & 94.2 & 38.7 & 67.9 & 97.5 & 49.3 \\
\hline 6 & & 45 & 1200 & 125 & $1: 2: 2: 3$ & 74.3 & 90.5 & 38.0 & 71.5 & 92.0 & 49.0 \\
\hline 7 & & 67 & 1200 & 105 & $1: 2: 2: 3$ & 53.0 & 95.0 & 28.4 & 52.5 & 98.0 & 38.3 \\
\hline 8 & & 67 & 1200 & 115 & $1: 2: 2: 3$ & 57.1 & 93.1 & 30.0 & 59.3 & 97.7 & 43.4 \\
\hline 9 & & 67 & 1200 & 125 & $1: 2: 1: 3$ & 60.0 & 89.2 & 30.2 & 63.1 & 90.2 & 42.3 \\
\hline 10 & \multirow{6}{*}{ 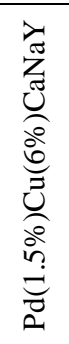 } & 45 & 1200 & 115 & $1: 2: 1: 4$ & 63.4 & 97.3 & 34.8 & 66.8 & 98.0 & 48.7 \\
\hline 11 & & 45 & 1200 & 115 & $1: 2: 3: 2$ & 70.5 & 91.9 & 36.6 & 69.5 & 96.8 & 50.1 \\
\hline 12 & & 45 & 1200 & 115 & $1: 1: 2: 4$ & 62.7 & 92.3 & 32.8 & 60.3 & 96.9 & 43.5 \\
\hline 13 & & 45 & 1200 & 115 & $1: 3: 2: 2$ & 67.3 & 95.6 & 36.3 & 63.1 & 98.0 & 46.0 \\
\hline 14 & & 45 & 800 & 115 & $1: 2: 2: 3$ & 84.5 & 92.0 & 29.3 & 80.9 & 97.5 & 39.2 \\
\hline 15 & & 45 & 1600 & 115 & $1: 2: 2: 3$ & 55.6 & 95.3 & 39.9 & 53.0 & 97.8 & 51.3 \\
\hline 16 & \multirow{9}{*}{ 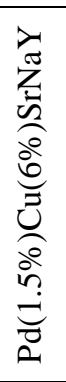 } & 29 & 1200 & 105 & $1: 2: 2: 3$ & 36.5 & 97.8 & 20.1 & 34.2 & 98.3 & 25.0 \\
\hline 17 & & 29 & 1200 & 115 & $1: 2: 2: 3$ & 40.0 & 95.9 & 21.7 & 39.1 & 97.7 & 28.4 \\
\hline 18 & & 29 & 1200 & 125 & $1: 2: 2: 3$ & 44.3 & 92.5 & 23.1 & 42.5 & 93.6 & 29.5 \\
\hline 19 & & 41 & 1200 & 105 & $1: 2: 2: 3$ & 41.8 & 97.0 & 22.9 & 37.3 & 97.8 & 27.2 \\
\hline 20 & & 41 & 1200 & 115 & $1: 2: 2: 3$ & 44.8 & 94.8 & 24.0 & 40.1 & 97.0 & 28.9 \\
\hline 21 & & 41 & 1200 & 125 & $1: 2: 2: 3$ & 49.8 & 91.1 & 25.5 & 44.9 & 93.2 & 31.2 \\
\hline 22 & & 57 & 1200 & 105 & $1: 2: 2: 3$ & 43.2 & 95.5 & 23.3 & 40.0 & 97.3 & 28.9 \\
\hline 23 & & 57 & 1200 & 115 & $1: 2: 2: 3$ & 45.3 & 93.5 & 23.9 & 42.6 & 96.1 & 30.4 \\
\hline 24 & & 57 & 1200 & 125 & $1: 2: 2: 3$ & 50.4 & 90.3 & 25.1 & 46.3 & 91.9 & 31.7 \\
\hline 25 & \multirow{9}{*}{ 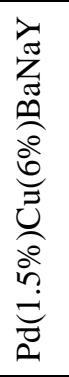 } & 33 & 1200 & 105 & $1: 2: 2: 3$ & 25.3 & 98.7 & 14.1 & 23.0 & 99.0 & 17.0 \\
\hline 26 & & 33 & 1200 & 115 & $1: 2: 2: 3$ & 30.0 & 97.0 & 16.4 & 27.0 & 97.3 & 19.6 \\
\hline 27 & & 33 & 1200 & 125 & $1: 2: 2: 3$ & 34.6 & 93.9 & 18.3 & 30.4 & 94.0 & 21.3 \\
\hline 28 & & 50 & 1200 & 105 & $1: 2: 2: 3$ & 29.5 & 97.6 & 16.3 & 25.9 & 97.5 & 18.7 \\
\hline 29 & & 50 & 1200 & 115 & $1: 2: 2: 3$ & 34.1 & 95.6 & 18.4 & 31.1 & 96.2 & 22.2 \\
\hline 30 & & 50 & 1200 & 125 & $1: 2: 2: 3$ & 36.7 & 92.7 & 19.2 & 34.0 & 94.0 & 23.8 \\
\hline 31 & & 60 & 1200 & 105 & $1: 2: 2: 3$ & 19.4 & 96.8 & 10.6 & 16.5 & 99.4 & 12.2 \\
\hline 32 & & 60 & 1200 & 115 & $1: 2: 2: 3$ & 21.1 & 95.0 & 11.3 & 19.5 & 97.2 & 14.1 \\
\hline 33 & & 60 & 1200 & 125 & $1: 2: 2: 3$ & 26.3 & 92.0 & 13.7 & 22.8 & 95.1 & 10.2 \\
\hline
\end{tabular}

With the purpose of the development a high efficiency catalyst for the reaction of oxidative conversion of methane into ethylene have been synthesized by ion exchange a range of the metalzeolite catalyst on the basis of natural (pure and dealuminated clinoptilolite and mordenite) zeolites and the cations of different metals $\left(\mathrm{Mg}^{2+}, \mathrm{Ca}^{2+}, \mathrm{Ba}^{2+}, \mathrm{Li}^{+}\right)$. The test of the activity of these catalysts have been carried out at atmospheric pressure in the range of temperature $(700-800)^{0} \mathrm{C}$, space velocity, (7000-18000) $\mathrm{h}^{-1}$ and mole ratio of the reagents $\mathrm{CH}_{4}: \mathrm{O}_{2}=1.0: 2.5$. Some of the results of this investigation are given in Table 2 .

Comparative analysis of the data of Table 2 on activity and selectivity of the mordenites and clinoptilolites in the reaction of oxidative conversion of methane shows that the best results are obtained over pure and dealuminated Azerbaijan natural clinoptilolite, with increasing 
silicate modulus of the clinoptilolite increases his activity and selectivity.

Therefore the metalzeolite catalysts were synthesized on the basis of dealuminated clinoptilolite with the silicate modulus 10.8 . It can be seen from data of Table 2 the best activity shows the dealuminated clinoptilolite containing of ions of calcium. The increasing of concentration of ions of calcium from 5 to $7 \%$ (\% from weight of catalyst) increases of the activity of metalzeolite catalyst, the further increasing of concentration of ions of calcium does not significantly influence on the activity of metalzeolite catalyst, Clin $\mathrm{Ca}$ (exp. 11-14).

With the purpose of the increasing of the selectivity of the process, this catalyst was modified by ions of lithium. In increasing of content of ions of lithium from $3 \%$ (wt.) to $8 \%$ (wt.) result in the increasing of the selectivity of the process in all of concentration of ions of calcium (exp. № 20-24). It can be followed from the data of Table 2, the best result are obtained over metalzeolite catalyst - Clin. (silicate module $=10.8$ ) $\mathrm{Ca} \mathrm{Li}$ containing $7.0 \%$ (wt.) of ions $\mathrm{Ca}^{2+}$ and $8.0 \%$ (wt.) of ions $\mathrm{Li}$.

It has also been investigated and activity of these metalzeolite catalysts in the reaction of partial oxidation of propane into acetaldehyde and formaldehyde at atmospheric pressure in the range of change of temperature $(320-370)^{0} \mathrm{C}$; space velocity (500-2500) $\mathrm{h}^{-1}$ and molar ratio of reagents $\mathrm{C}_{3} \mathrm{H}_{8}: \mathrm{O}_{2}=0.5-1.2$. Some of results of this investigation are given in Table 3 .

It can be seen from the data of Table 4 clinoptilolite containing $1.0 \%$ (wt.) of cations $\mathrm{Ni}^{2+}$ shows relatively high catalytic activity in reaction of oxidative conversion of propylene to acrolein (exp. 6, 7, 8). Over this catalyst the yield of acrolein is $80.0 \%$ at the selectivity of process $85.0 \%$

Table 2. The results on the selection of active catalyst for the reaction oxidative conversion of methane into ethylene at space velocity $\mathrm{V}=16000 \mathrm{~h}^{-1}$, mole ratio $\mathrm{CH}_{4}: \mathrm{O}_{2}=0.402: 0.312$

\begin{tabular}{|c|c|c|c|c|c|c|c|}
\hline \multirow{2}{*}{ № } & \multirow{2}{*}{ Catalyst } & \multirow{2}{*}{$T,{ }^{0} \mathrm{C}$} & \multirow{2}{*}{$\begin{array}{c}\text { Conversion of } \\
\mathrm{CH}_{4} \mathrm{~mol} \%\end{array}$} & \multicolumn{2}{|c|}{ Yield, \% } & \multicolumn{2}{|c|}{ Selectivity, \% } \\
\hline & & & & $\mathrm{C}_{2} \mathrm{H}_{4}$ & $\mathrm{C}_{2} \mathrm{H}_{6}$ & $\mathrm{C}_{2} \mathrm{H}_{4}$ & $\mathrm{C}_{2} \mathrm{H}_{6}$ \\
\hline 1 & Clinoptilolite (pure) & 800 & 9.5 & 3.39 & 3.35 & 25.2 & 35.3 \\
\hline 2 & Mordenite (pure) & 800 & 5.4 & 1.30 & 1.79 & 24.1 & 33.3 \\
\hline 3 & Clinoptilolite (8.68) & 800 & 12.7 & 3.35 & 4.64 & 26.4 & 36.3 \\
\hline 4 & Clinoptilolite (9.80) & 800 & 15.8 & 4.45 & 6.03 & 28.2 & 38.2 \\
\hline 5 & Clinoptilolite(10.80) & 800 & 19.9 & 5.93 & 7.50 & 29.3 & 37.7 \\
\hline 6 & Mordenite I HCl & 800 & 7.3 & 1.79 & 2.54 & 24.6 & 34.9 \\
\hline 7 & Mordenite II HCl & 800 & 10.9 & 2.89 & 3.65 & 26.6 & 33.5 \\
\hline 8 & Clin(10.8) $\mathrm{Mg}(5 \%)$ & 800 & 36.4 & 5.64 & 7.17 & 15.5 & 19.7 \\
\hline 9 & Clin(10.8)Mg(7\%) & 800 & 40.2 & 7.35 & 7.67 & 18.3 & 19.1 \\
\hline 10 & Clin(10.8)Mg(10\%) & 800 & 41.0 & 7.38 & 8.40 & 18.0 & 20.5 \\
\hline 11 & Clin(10.8) $\mathrm{Ca}(5 \%)$ & 800 & 35.9 & 6.64 & 7.72 & 18.5 & 21.5 \\
\hline 12 & $\mathrm{Clin}(10.8) \mathrm{Ca}(7 \%)$ & 800 & 39.8 & 7.84 & 8.95 & 19.7 & 22.5 \\
\hline 13 & Clin(10.8)Ca(10\%) & 800 & 40.7 & 8.34 & 9.40 & 20.5 & 23.1 \\
\hline 14 & Clin(10.8)Sr(5\%) & 800 & 33.2 & 5.04 & 5.97 & 15.2 & 18.0 \\
\hline 15 & Clin(10.8)Sr(7\%) & 800 & 34.3 & 5.28 & 6.48 & 15.4 & 18.4 \\
\hline 16 & Clin(10.8)Sr(10\%) & 800 & 35.5 & 5.75 & 6.46 & 16.2 & 18.2 \\
\hline 17 & Clin(10.8)Ba(5\%) & 800 & 31.5 & 4.44 & 5.29 & 14.1 & 16.8 \\
\hline 18 & $\mathrm{Clin}(10.8) \mathrm{Ba}(7 \%)$ & 800 & 32.0 & 4.73 & 5.18 & 14.8 & 16.2 \\
\hline 19 & Clin(10.8)Ba(10\%) & 800 & 33.4 & 5.14 & 5.64 & 15.4 & 16.9 \\
\hline 20 & Clin(10.8)Ca(7\%)Li(3\%) & 700 & 58.8 & 14.31 & 12.59 & 26.6 & 23.4 \\
\hline 21 & Clin(10.8)Ca(7\%)Li(5\%) & 700 & 54.9 & 14.98 & 13.94 & 27.3 & 25.4 \\
\hline 22 & Clin(10.8)Ca(7\%)Li(8\%) & 700 & 58.2 & 17.51 & 14.55 & 30.1 & 25.0 \\
\hline 23 & Clin(10.8)Ca(5\%)Li(8\%) & 700 & 53.0 & 13.80 & 13.55 & 26.2 & 25.2 \\
\hline 24 & $\operatorname{Clin}(10.8) \mathrm{Ca}(10 \%) \operatorname{Li}(8 \%)$ & 700 & 53.8 & 16.73 & 10.86 & 31.1 & 20.2 \\
\hline
\end{tabular}


It can be seen from data of Table 3 dealuminated clinoptilolite containing of ions of tin and lithium significantly increases of the selectivity of the processed and the yield of formaldehyde and acetaldehyde (exp. 16, 17, 18). The best results are obtained over the metalzeolite catalyst, Clin (10.8) $\mathrm{Ca}(8 \%) \mathrm{Sn}(7 \%) \mathrm{Li}(7 \%)$.
The results on the selection of active catalyst for the reaction of oxidative conversion of propylene to acrolein are presented in Table $4[9-10]$.

The reaction of oxidative conversion of methane into ethylene and acetylene is carried out in a two-stage reactor.

Table 3. The results of investigation on selection of active catalyst for the reaction of partial oxidation of propane.

Space velocity $V=1000 \mathrm{~h}^{-1}$, molar ratio $\mathrm{C}_{3} \mathrm{H}_{8}: \mathrm{O}_{2}=0,5$

\begin{tabular}{|c|c|c|c|c|c|c|c|c|}
\hline \multirow[b]{2}{*}{ № } & \multirow[b]{2}{*}{ Catalyst } & \multirow[b]{2}{*}{ 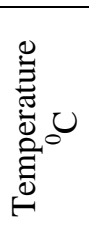 } & \multirow[b]{2}{*}{ 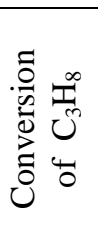 } & \multicolumn{5}{|c|}{ Yield, $\%$} \\
\hline & & & & $\begin{array}{l}\mathbb{T}_{0} \\
\stackrel{0}{I}\end{array}$ & $\begin{array}{l}\mathbb{T} \\
0 \\
0 \\
0 \\
0 \\
0 \\
0\end{array}$ & 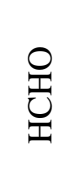 & $\overbrace{}^{N}$ & $\begin{array}{l}\stackrel{0}{U} \\
\underset{N}{U} \\
\stackrel{U}{U}\end{array}$ \\
\hline 1 & Clin (Pure) & 350 & 5.6 & 0.6 & - & 1.6 & 1.0 & 2.4 \\
\hline 2 & Mord (Pure) & 350 & 3.4 & 0.3 & - & 0.6 & 1.4 & 1.1 \\
\hline 3 & Clin (10.8) & 350 & 8.4 & 1.1 & - & 2.0 & 2.1 & 3.2 \\
\hline 4 & Mord (dealum) & 350 & 6.2 & 0.9 & - & 1.4 & 1.9 & 2.0 \\
\hline 5 & Clin (10.8) Mg (5\%) & 330 & 35.1 & 3.8 & 0.8 & 9.3 & 11.0 & 10.2 \\
\hline 6 & Clin (10.8) Mg (10\%) & 330 & 36.4 & 2.9 & 1.2 & 8.8 & 13.6 & 9.9 \\
\hline 7 & Clin (10.8) $\mathrm{Ca}(5 \%)$ & 330 & 36.6 & 2.5 & 1.6 & 11.8 & 5.8 & 15.1 \\
\hline 8 & Clin (10.8) Ca (10\%) & 330 & 37.4 & 2.2 & 1.7 & 12.7 & 5.2 & 15.6 \\
\hline 9 & Clin (10.8) Sr (5\%) & 330 & 35.7 & 2.9 & 1.0 & 10.5 & 10.1 & 11.2 \\
\hline 10 & Clin (10.8) Sr (10\%) & 330 & 36.0 & 2.8 & 1.2 & 10.2 & 10.0 & 10.8 \\
\hline 11 & Clin (10.8) Ba (5\%) & 330 & 33.1 & 1.7 & 0.9 & 11.1 & 9.5 & 9.9 \\
\hline 12 & Clin (10.8) $\mathrm{Ba}(10 \%)$ & 330 & 33.8 & 1.9 & 1.0 & 11.8 & 9.3 & 9.8 \\
\hline 13 & Clin (10.8) Sn (5\%) & 330 & 34.5 & 1.5 & 2.1 & 7.9 & 14.2 & 8.8 \\
\hline 14 & Clin (10.8) Sn (7\%) & 330 & 35.0 & 1.8 & 2.2 & 7.5 & 15.1 & 8.4 \\
\hline 15 & Clin (10.8) $\mathrm{Ca}(8 \%) \mathrm{Sn}(7 \%)$ & 330 & 52.0 & 2.1 & 2.6 & 10.2 & 16.9 & 20.2 \\
\hline 16 & Clin (10.8) Ca (8\%) Sn (7\%)Li(3\%) & 360 & 56.0 & 2.0 & 5.2 & 15.8 & 7.8 & 25.2 \\
\hline 17 & Clin (10.8) Ca (8\%) Sn (7\%)Li(5\%) & 360 & 60.0 & 2.1 & 6.1 & 18.7 & 5.0 & 28.1 \\
\hline 18 & Clin (10.8) $\mathrm{Ca}(8 \%) \mathrm{Sn}(7 \%) \mathrm{Li}(7 \%)$ & 360 & 63.1 & 1.8 & 7.3 & 20.2 & 3.6 & 30.6 \\
\hline
\end{tabular}

Table 4. The results on the selection of active catalyst for the reaction oxidative conversion of propylene to acrolein $\left(T=380^{\circ} \mathrm{C}, V=800 \mathrm{~h}^{-1}, \mathrm{C}_{3} \mathrm{H}_{6}: \mathrm{O}_{2}=1.0: 1.2\right)$

\begin{tabular}{|c|c|c|c|c|c|c|c|}
\hline \multirow{2}{*}{$№$} & \multirow{2}{*}{ Catalyst } & \multirow{2}{*}{$\mathrm{X}, \%$} & $\mathrm{~S}, \%$ & \multicolumn{4}{|c|}{ Yield, \% } \\
\cline { 5 - 8 } & & & $\mathrm{CO}_{2}$ & $\mathrm{CH}_{2} \mathrm{O}$ & $\mathrm{C}_{3} \mathrm{H}_{4} \mathrm{O}$ & $\mathrm{HCOOH}$ \\
\hline 1 & $\mathrm{Zn}(0.2 \%)$ & 37.50 & 5.25 & 22.13 & 13.40 & 1.97 & - \\
\hline 2 & $\mathrm{Cu}(0.5 \%)$ & 58.25 & - & 38.65 & 19.60 & - & - \\
\hline 3 & $\mathrm{Co}(0.5 \%)$ & 59.81 & - & 46.37 & 13.44 & - & - \\
\hline 4 & $\mathrm{Mg}(1 \%)$ & 62.99 & 68.52 & 8.86 & 10.31 & 43.16 & 0.66 \\
\hline 5 & $\mathrm{Pd}(1 \%)$ & 60.37 & - & 53.37 & 7.00 & - & - \\
\hline 6 & $\mathrm{Ni}(1 \%)$ & 94.72 & 85.44 & 5.44 & 5.75 & 80.93 & 2.60 \\
\hline 7 & $\mathrm{Ni}(3 \%)$ & 69.83 & 68.85 & 11.96 & 4.19 & 48.08 & 5.60 \\
\hline 8 & $\mathrm{Ni}(5 \%)$ & 74.00 & 48.70 & 25.74 & 8.02 & 36.04 & 4.20 \\
\hline 9 & $\mathrm{CuFe}(0.5: 0.25)$ & 56.00 & 18.03 & 29.8 & 15.70 & 10.10 & 0.40 \\
\hline 10 & $\mathrm{CuPd}(0.5: 0.25)$ & 50.03 & - & 50.03 & - & - & - \\
\hline 11 & $\mathrm{CoBi}(0.5: 1)$ & 53.83 & 26.56 & 24.09 & 15.07 & 14.3 & 0.37 \\
\hline 12 & $\mathrm{ZnCoCr}(0.2: 0.5: 0.25)$ & 68.35 & 65.00 & 14.96 & 8.40 & 44.43 & 0.56 \\
\hline 13 & $\mathrm{CuPdZn}(2: 1: 2)$ & 65.52 & - & 65.52 & - & - & - \\
\hline 14 & $\mathrm{CuMnCo}(1: 0.5: 0.5)$ & 51.41 & 16.69 & 33.25 & 9.34 & 8.58 & 0.24 \\
\hline
\end{tabular}


The same catalyst were employed in the first and the second reactors with volumes of beds $\mathrm{V}_{\text {cat }}^{\prime}=\mathrm{V}_{\text {cat }}^{\prime \prime}=0.5 \mathrm{~cm}^{3}$. At the exit from the stage I contact gas contains $\mathrm{C}_{2} \mathrm{H}_{6}, \mathrm{C}_{2} \mathrm{H}_{4}, \mathrm{H}_{2}$, $\mathrm{CO}_{2}$ and trace amount of $\mathrm{CO}$. At the exit of the second stage in the contact gas $\mathrm{CO}$ were deleted. The results on the selection of active catalyst for the reaction of oxidative conversion of methane into ethylene and acetylene are presented in Table 5.

It can be seen from the data of Table 5 from not modified with metal cations of zeolites the best activity in this reaction shows natural clinoptilolite (exp. 1-4). The increasing of silicate modulus increases of the catalytic activity of clinoptilolite (exp. 1-2). Modified by cations $\mathrm{Mg}^{2+}$ and $\mathrm{Ca}^{2+}$ natural clinoptilolite (silicate modulus $=10.8$ ) has relatively high catalytic activity (exp. 5-10). The best results are obtained over metalzeolite catalyst clinoptilolite with silicate modulus 10.8 containing $10.0 \%$ (wt.) of $\mathrm{Ca}^{2+}$ cations (exp. $10)$. With the purpose of the increasing of the selectivity of the process this catalyst was modified by cations of lithium (exp. 11-19). It can be seen from these data incorporation of cations on lithium increases of selectivity and activity of the catalyst. It can be explained by decreasing the rate of reaction of deep oxidation. The catalyst were prepared on the basis of clinoptilolite with silicate modulus 10.8 and cations of $\mathrm{Mn}^{2+}$ have less activity on comparison with the catalyst (exp. 20-22) containing cations $\mathrm{Ca}^{2+}$ and $\mathrm{Li}^{+}$.

Table 5. The results on the selection of active catalyst for the reaction oxidative conversion of methane to ethylene and acetylene.

\begin{tabular}{|c|c|c|c|c|c|c|c|c|}
\hline \multirow{2}{*}{ № } & \multirow{2}{*}{ Catalyst } & \multirow{2}{*}{$\mathrm{T}^{1},{ }^{0} \mathrm{C}$} & \multirow{2}{*}{$\mathrm{T}^{20},{ }^{0} \mathrm{C}$} & \multirow{2}{*}{$\mathrm{X}, \%$} & \multicolumn{4}{|c|}{ Yield, \% } \\
\hline & & & & & $\mathrm{C}_{2} \mathrm{H}_{4}$ & $\mathrm{C}_{2} \mathrm{H}_{2}$ & $\mathrm{C}_{2} \mathrm{H}_{6}$ & $\mathrm{CO}_{2}$ \\
\hline 1 & Clinoptilolite (8.6) & 800 & 600 & 19.9 & 5.93 & 7.50 & 0.6 & 5.4 \\
\hline 2 & Mordenite & 800 & 600 & 5.4 & 1.3 & 1.79 & 0.3 & 1.7 \\
\hline 3 & Clinoptilolite(10.8) HCL & 800 & 600 & 27.7 & 6.21 & 7.10 & 0.5 & 13.1 \\
\hline 4 & Mordenite & 800 & 600 & 10.9 & 2.89 & 3.65 & 0.2 & 4.16 \\
\hline 5 & Clin(10.8) Mg(5\%) & 800 & 600 & 36.4 & 5.64 & 7.17 & 0.2 & 22.8 \\
\hline 6 & Clin(10.8)Mg(7\%) & 800 & 600 & 40.4 & 7.35 & 7.67 & 0.2 & 24.3 \\
\hline 7 & Clin(10.8)Mg(10\%) & 800 & 600 & 41.0 & 7.28 & 8.40 & 0.3 & 24.8 \\
\hline 8 & Clin(10.8)Ca(5\%) & 800 & 600 & 35.9 & 6.64 & 7.72 & 0.25 & 20.5 \\
\hline 9 & Clin(10.8)Ca(7\%) & 800 & 600 & 39.8 & 7.84 & 8.95 & 0.3 & 22.1 \\
\hline 10 & Clin(10.8)Ca(10\%) & 800 & 600 & 40.7 & 8.34 & 9.40 & 0.4 & 22.1 \\
\hline 11 & Clin(10.8)Ca(5\%)Li(3\%) & 800 & 600 & 51.1 & 12.82 & 11.75 & 0.5 & 25.6 \\
\hline 12 & Clin(10.8) $\mathrm{Ca}(5 \%) \operatorname{Li}(5 \%)$ & 800 & 600 & 52.2 & 13.31 & 12.37 & 0.5 & 25.4 \\
\hline 13 & Clin(10.8)Ca(5\%)Li(7\%) & 800 & 600 & 53.0 & 13.80 & 13.35 & 0.6 & 24.9 \\
\hline 14 & Clin(10.8)Ca(7\%)Li(3\%) & 800 & 600 & 58.8 & 14.31 & 12.59 & 0.65 & 30.8 \\
\hline 15 & Clin(10.8)Ca(7\%)Li(5\%) & 800 & 600 & 54.9 & 14.98 & 13.94 & 0.67 & 24.83 \\
\hline 16 & Clin(10.8)Ca(7\%)Li(7\%) & 800 & 600 & 58.2 & 17.51 & 14.55 & 0.81 & 25.0 \\
\hline 17 & Clin(10.8)Ca(10\%)Li(3\%) & 800 & 600 & 51.5 & 15.70 & 9.63 & 0.64 & 25.1 \\
\hline 18 & Clin(10.8)Ca(10\%)Li(5\%) & 800 & 600 & 53.5 & 16.37 & 9.73 & 0.57 & 26.83 \\
\hline 19 & Clin(10.8)Ca(10\%)Li(7\%) & 800 & 600 & 53.8 & 16.73 & 10.86 & 0.9 & 24.94 \\
\hline 20 & Clin $(10.8) \mathrm{Ca}(5 \%) \operatorname{Li}(5 \%)$ & 800 & 600 & 29.7 & 6.78 & 6.72 & 0.41 & 14.9 \\
\hline 21 & Clin(10.8)Mn(5\%) & 800 & 600 & 32.8 & 7.61 & 6.79 & 0.42 & 17.4 \\
\hline 22 & Clin(10.8)Mn(7\%) & 800 & 600 & 36.3 & 8.37 & 6.53 & 0.50 & 19.9 \\
\hline 23 & Clin(10.8)Li(5\%)Mg(3\%) & 800 & 600 & 47.0 & 9.2 & 7.3 & 0.8 & 29.4 \\
\hline 24 & Clin(10.8)Li(5\%)Mg(5\%) & 800 & 600 & 40.7 & 12.1 & 8.1 & 0.74 & 19.3 \\
\hline 25 & Clin(10.8)Li(7\%)Mg(7\%) & 800 & 600 & 31.3 & 11.6 & 7.6 & 0.73 & 10.9 \\
\hline 26 & Clin(10.8) $\operatorname{Mg}(5 \%) \operatorname{Mn}(7 \%)$ & 800 & 600 & 38.8 & 7.3 & 6.8 & 0.54 & 23.9 \\
\hline 27 & $\operatorname{Clin}(10.8) \operatorname{Mg}(7 \%) \operatorname{Mn}(7 \%)$ & 800 & 600 & 41.2 & 10.9 & 8.3 & 0.62 & 20.83 \\
\hline 28 & Clin(10.8)Li(7\%)Mg(7\%) & 800 & 600 & 65.0 & 26.0 & 13.0 & 0.7 & 24.9 \\
\hline 29 & $\operatorname{Clin}(10.8) \mathrm{Ca}(8 \%) \operatorname{Li}(7 \%) \operatorname{Mg}(5 \%)$ & 800 & 600 & 68.2 & 19.1 & 13.1 & 0.76 & 34.86 \\
\hline 30 & Clin(10.8)Ca(8\%) Li(5\%)Mg(8\%) & 800 & 600 & 73.0 & 20.44 & 13.2 & 0.63 & 38.3 \\
\hline 31 & Clin(10.8)Ca(8\%) Li(7\%)Mg(8\%) & 800 & 600 & 79.8 & 25.0 & 9.7 & 0.56 & 43.97 \\
\hline
\end{tabular}


Table 6. The results on the selection of active catalyst for the reaction oxidative conversion of methane into 1,4butanediol

\begin{tabular}{|c|c|c|c|c|c|c|c|c|}
\hline \multirow{2}{*}{ № } & \multirow{2}{*}{ Catalyst } & \multirow{2}{*}{$\mathrm{T}^{1},{ }^{0} \mathrm{C}$} & \multirow{2}{*}{$\mathrm{T}^{2},{ }^{0} \mathrm{C}$} & \multirow{2}{*}{$\mathrm{V} \mathrm{h}^{-1}$} & \multirow{2}{*}{$\mathrm{X}, \%$} & \multicolumn{3}{|c|}{ Yield, \% } \\
\hline & & & & & & $A_{B D}$ & $\mathrm{~A}_{\mathrm{C} 2 \mathrm{H} 2}$ & $\mathrm{~A}_{\mathrm{C} 2 \mathrm{H} 4}$ \\
\hline 1 & Clin(10.8) Mn(8.0\%) & 815 & 600 & 16000 & 36.3 & 2.6 & 14.9 & 1.3 \\
\hline 2 & & 815 & 600 & 16000 & 35.7 & 2.2 & 14.8 & 1.5 \\
\hline 3 & & 815 & 630 & 19000 & 29.7 & 2.0 & 13.5 & 1.0 \\
\hline 4 & Clin(10.8) $\mathrm{Mn}(8.0 \%) \operatorname{Li}(7.0 \%) \mathrm{Ni}(8.0 \%)$ & 800 & 600 & 19000 & 53.8 & 8.0 & 11.5 & 2.8 \\
\hline 5 & & 800 & 700 & 16000 & 66.33 & 8.7 & 7.0 & 2.1 \\
\hline 6 & & 800 & 600 & 16000 & 46.33 & 6.2 & 4.7 & 1.9 \\
\hline 7 & Clin(10.8) $\mathrm{Mn}(8.0 \%) \operatorname{Li}(7.0 \%) \mathrm{Ni}(8.0 \%)$ & 770 & 600 & 16000 & 80.2 & 23.1 & 4.4 & 2.3 \\
\hline 8 & & 670 & 650 & 16000 & 63.3 & 15.9 & 2.9 & 1.5 \\
\hline 9 & & 750 & 650 & 16000 & 64.2 & 17.3 & 4.4 & 2.8 \\
\hline 10 & & 800 & 650 & 16000 & 72.8 & 22.3 & 5.9 & 3.9 \\
\hline 11 & & 800 & 700 & 25200 & 59.4 & 14.9 & 3.4 & 3.0 \\
\hline
\end{tabular}

$\mathrm{A}_{\mathrm{BD}}$-yield of 1,4-butandiol

Incorporation of cations of lithium in $\mathrm{Mg}^{2+}$ containing clinoptilolite is also increased catalytic activity (exp. 23-25) on comparison with clinoptilolite containing only cations $\mathrm{Mg}^{2+}$ (exp. 5-7). It can be explained by decreasing of fraction of reaction of deep oxidation of methane. Clinoptilolite containing cations of $\mathrm{Mg}^{2+}$ and $\mathrm{Mn}^{2+}$ (exp. 26-27) has relatively high activity on comparison with catalysts containing only cations of $\mathrm{Mg}^{2+}$ (exp. 5-7), that can be explained by improving of distribution of the active centers on the surface of catalyst at incorporation in the clinoptilolite of $\mathrm{Mn}^{2+}$ cations.

Optimum distribution of the active centers on the surface of catalyst for reaction of oxidative conversion of methane to ethylene and acetylene is reached by modified of natural clinoptilolite with silicate modulus 10.8 with cations: $\mathrm{Ca}^{2+}, \mathrm{Mg}^{2+}$ and $\mathrm{Li}^{+}$(exp. 28-31). By means of variation of concentrations of the cations it has been determined the active consist of the catalyst Clin(10.8) $\mathrm{Ca}(8.0 \%) \mathrm{Li}(7.0 \%)$ $\operatorname{Mg}(8.0 \%)$ (exp. 31) [11-14].

On the basis of natural clinoptilolite with silicate modulus 10.8 we are also synthesized the modified with cations $\mathrm{Mn}^{2+}, \mathrm{Mg}^{2+}, \mathrm{Li}^{+}$and $\mathrm{Ni}^{2+}$ zeolite catalysts for reaction of oxidative conversion of methane to 1,4-buthanediol. Activity of the prepared metalzeolite catalysts were carried out in a two-stage reactor with stepped feed of oxygen volumes of beds $\mathrm{V}_{\text {cat }}^{\prime}=\mathrm{V}_{\text {cat }}^{\prime \prime}=0.5 \mathrm{~cm}^{3}$ of the same catalyst. The analyses of the liquid products of the reaction were performed by gas chromatograph Agilent
7820 using FID, a capillary column, DB-624 (length, $60 \mathrm{~m}$ ) and helium as the carrier gas.

The results on the selection of active catalyst for this reaction given in Table 6 .

It can be seen from data of Table 6 clinoptilolite (silicate module $=10.8$ ) containing $8.0 \%$ (wt.) of cations $\mathrm{Mn}^{2+}$ shows catalytic activity in the reaction of oxidative conversion of methane to 1,4-butandiol (exp. 1-3). The incorporating in this catalyst cations $\mathrm{Li}^{+}$and $\mathrm{Ni}^{2+}$ increases its activity (exp. 4-6). The best activity shows the dealuminated clinoptilolite (silicate module $=10.8$ ) containing $8.0 \%$ (wt.) $\mathrm{Mn}^{2+}, 7.0 \%$ (wt.) $\mathrm{Li}$ and $8.0 \%$ (wt.) $\mathrm{Ni}^{2+}$ (exp. 7-11).

\section{Conclusion}

It has been synthesized by ion exchange method a range of the metalzeolite catalysts for reactions of the oxidative conversion of the lower olefins and paraffins on the basis of synthetic $(\mathrm{NaY})$ and natural (pure and dealuminated clinoptilolite and mordenite) zeolites and the cations of different metals $\left(\mathrm{Pd}^{2+}\right.$, $\left.\mathrm{Cu}^{2+}, \mathrm{Mg}^{2+}, \mathrm{Mn}^{2+}, \mathrm{Ca}^{2+}, \mathrm{Ba}^{2+}, \mathrm{Ni}^{2+}, \mathrm{Sn}^{2+}, \mathrm{Li}^{+}\right)$. It has been established that the metalzeolite catalysts prepared on the basis of synthetic zeolite $\mathrm{NaY}$ and the cations of the metals $\mathrm{Pd}^{2+}$, $\mathrm{Cu}^{2+}, \mathrm{Ca}^{2+}, \mathrm{Sr}^{2+}$ and $\mathrm{Ba}^{2+}$ shows relatively high activity in the oxidative conversion of ethylene and propylene into acetaldehyde and acetone accordingly. The results on selection of the active metalzeolite catalyst for the reaction of the oxidative conversion of methane into ethylene have been shown that the best results were obtained over the metalzeolite catalyst contai- 
ning dealuminated clinoptilolite (silicate modulus =10.8) and cations $\mathrm{Ca}^{2+}$ and $\mathrm{Li}^{+}$. It has been also shown that metalzeolite containing dealuminated clinoptilolite (with silicate modulus $=10.8$ ) and cations, $\mathrm{Ca}^{2+}, \mathrm{Sn}^{2+}$ and $\mathrm{Li}^{+}$shows the highest activity in oxidative conversion of propane into acetaldehyde and formaldehyde. Propylene is converted to acrolein at $320-380^{\circ} \mathrm{C}$ with more than $85 \%$ selectivity over clinoptilolite containing $1 \%$ (wt.) of $\mathrm{Ni}^{2+}$. Natural clinoptilolite with silicate modulus -10.8 containing cations $\mathrm{Li}^{+}, \mathrm{Ca}^{2+}$ and $\mathrm{Mg}^{2+}$ shows relatively high catalytic activity in the oxidative conversion of methane to ethylene and acetylene in a two-stage reactor with stepped feed of oxygen. Oxidative conversion of methane to 1,4-butanediol proceeds in a twostage reactor with a stepped feed of oxygen over clinoptilolite (10.8) containing cations $\mathrm{Mn}^{2+}, \mathrm{Li}^{+}$and $\mathrm{Ni}^{2+}$, catalyst.

All of the metalzeolite catalyst presented in the article were tested in a laboratory scale during 300 hours and was not observed any change of catalytic activity for all of the catalyst. The result of the presented experimental investigations show that on the basis of zeolites and metal cations with known catalytic properties by ion exchange method may be synthesized efficiency metalzeolite catalyst for the different reactions.

\section{References}

1. Aria H., Lamasharo T., Kubo T., Tominaga H. The catalysis of palladium and cupric ion exchanged zeolite for oxidation of ethylene. Bull. Jap. Petrol. Inst. 1976. 18(1). P. 39-46.

2. Minachev KH.M., Usachev N.Ia., Rodin A.P., Kalinin V.P., Isakov Ia.I. Okisleniia etilena i propilena $\mathrm{v}$ karbonilnye soedineniia na tceolitnykh katalizatorakh. Tez. docl. I Neftehim. Simpoz. sotc. stran. Baku, noiabr. 1978. M.: Nauka. S. 92-93.
3. Shakhtakhtinskii T.N., Benni Kh.F., Aliev A.M., Kuliev A.R., Kasamanskii V.P., Peresada I.M. Podbor Pd- i Su-soderzhashchego tceolitnogo katalizatora dlia gazofaznoi reaktcii okisleniia etilena $\mathrm{v}$ atcetaldegid.. Azerb. Chem. Journ. 1979. No 2. P. 41-50.

4. Shakhtakhtinskii T.N., Benni Kh.F., Aliev A.M., Kuliev A.R., Kasamanskii V.P., Mikailov R.Z. Issledovanie reaktcii gazofaznogo okisleniia etilena na Pd- i Cu-soderzhashchikh tceolitnykh katalizatorakh. Azerb. Chem. Journ. 1979. No 2. P. 51-57.

5. Sittin M. Protcessy okisleniia uglerodnogo syria. M.:Himiia, 1970. C. 62.

6. Safarov M.G., Balaev F.A. Okislenie propana na vanadievy`kh katalizatorax. Tez. docl. V konf. po okislitel nomu geterogennomu katalizu. T. 2. 1981. S. 320-321.

7. Avtorskoe svidetel`stvo SSSR №706108. 1978.

8. Shakhtakhtinskii T.N., Aliev A.M. Pat. (Rossiia) Su1826925 Az 07.07.93. Katalizatory dlia partcialnogo okisleniia propana.

9. Aliev A.M., Gusei`nova T.I., Sary`dzhanov A.A., Safarov A.R., Bakhmanov M.F., Agaeva R.Iu., Nadzhaf-Guliev U.M., Iaryev V.M. Podbor aktivnogo modifitcirovannogo tceolitnogo katalizatora i izuchenie kinetiki i mehanizma reaktcii okislitelnogo prevrashcheniia propilena $v$ akrolein. Neftepererabotka i neftehimiia. 2019. № 5. S. 25-30.

10. Oliyev A.M., Nəcəf-Quliyev Ü.M., Sarıcanov Ә.Ә., Hüseynova T.İ., Yarıyev V.M., Süleymanov T.Y. Akroleinin alınma üsulu. Patent № İ 20200071.

11. Aliyev A.M., Matiyev K.I., Aliyev F.V., Agayeva R.Y. Investigation of mechanism of oxidative coupling of methane to $\mathrm{C}_{2}$-hydrocarbons. IX intern. conference mechanism of catalytic reactions. Saint Petersburg, 21-23 October, 2012, 22-24.

12. Aliyev A.M., Shabanova Z.A., Aliyev F.V., Guseynova A.M. Zeolites modified metal cations as catalysts in hydrocarbon oxidation and the alkyl alcohol. European Researcher. International Multidisciplinary Journal. 2014. 82. P. 9-1.

13. Oliyev A.M., Oliyev F.V., Motiyev K.I., Al-Dosari M.K. Asetilenin alınma üsulu. Patent № I 20160090.

14. Oliyev A.M., Oliyev F.V., Mətiyev K.I., Ağayev F.A., Səfərov A.R. 1,4-butandiolun alınma üsulu. Patent № I 20170005.

\section{MODIFIKASIIYA OLUNMUŞ SEOLIT KATALIZATORU ÜZəRINDĐ AŞAĞI OLEFINLəRIN Və PARAFINLORIN OKSIDLOŞDIRICI KONVERSIYASI}

\section{A.M.Oliyev, F.V.Oliyev, Ü.M.Nəcəf-Quliyev, R.İ.Đhmədov, T.İ Hüseynova, R.Y.Ağayeva}

Aşağı olefinlərin və parafinlərin neft-kimya sənayesinin istənilən məhsuluna çevrilmək üçün oksidləşdirici çevrilməsi reaksiyaları üçün yüksək effektivli katalizatorların hazırlanması məqsədi ilə sintetik (NaY) və təbii (təmiz və işlənmiş klinoptilolit və mordenit) seolitlər və müxtəlif metalların kationları əsasında bir sıra metalseolit katalizatorları ion mübadiləsi metodu ilə sintez edilmişdir. Sintetik seolit NaY əsasında hazırlanmış metalzeolit katalizatorlarının etilen və 
propilenin asetaldehid və asetona oksidləşdirici çevrilməsində nisbətən yüksək aktivlik göstərdiyi müəyyən edilmişdir. Həm də proseslər üçün yüksək effektivli bir metalzeolit katalizatorları sintez edilmişdir: metanın etilenə oksidləşdirici çevrilməsi; propanın asetaldehidə və formaldehidə oksidləşdirici çevrilməsi; metanın oksidləşmə ilə etilen və asetilenə çevrilməsi; metanın 1,4-butandiol-a oksidləşdirici çevrilməsi.

Açar sözlor: seolitlar, aktivlik, aşağı olefinlar, parafinlar, oksidləşmə.

\section{ОКИСЛИТЕЛЬНАЯ КОНВЕРСИЯ НИЗШИХ ОЛЕФИНОВ И ПАРАФИНОВ НА МОДИФИЦИРОВАННОМ ЦЕОЛИТНОМ КАТАЛИЗАТОРЕ}

\section{А.М.Алиев, Ф.В.Алиев, У.М.Наджаф-Кулиев, Р.И.Ахмедов, Т.И. Гусейнова, Р.Ю.Агаева}

С целью разработки высокоэффективных катализаторов реакций окислительного превращения низших олефинов и парафинов в желаемые продукты нефтехимической промышленности был синтезирован ионообменным методом ряд металцеолитовых катализаторов на основе синтетических (NaY) и природных (чистый и деалюминированный клиноптилолит и морденит) цеолитов и катионов различных металлов. Установлено, что металцеолитовые катализаторы, приготовленные на основе синтетического цеолита NaY, проявляют относительно высокую активность в окислительном превращении этилена и пропилена в ацетальдегид и ацетон соответственно. Также был синтезирован высокоэффективный металцеолитовый катализатор для процессов: окислительного превращения метана в этилен; окислительного превращения пропана в ацетальдегид и формальдегид; окислительного превращения метана в этилен и ацетилен; окислительного превращения метана в 1,4-бутандиол.

Ключевье слова: цееолиты, активность, низиие олефины, парафины, окислительная конверсия. 